\title{
•

\section{Peluquería y aseo: gusto francés y referentes de modernidad en el Santiago de Cuba decimonónico}

\author{
[Hairdressing and Grooming: French Taste and References of Modernity in \\ Nineteenth-Century Santiago de Cuba]
}

\author{
Aida Liliana Morales Tejeda \\ (Oficina del Conservador de la Ciudad de Santiago de Cuba, Cuba) \\ aida@occ.co.cu
}

\section{Resumen}

El presente ensayo centra su atención en la influencia que tuvieron los patrones franceses en la élite de la sociedad santiaguera decimonónica, en especial en temas como la moda y dentro de ellos la peluquería y el aseo. Este tema se revela como poderosa fuente para profundizar y evaluar los patrones del gusto que cohesionaban al grupo social dominante $y$ sus afanes exhibicionistas en un mundo de apariencias.

Palabras claves: Modernidad; Moda; Grupos Sociales Privilegiados; Ciudad de Santiago de Cuba.

\begin{abstract}
This essay focuses on the influence that French patterns had on the elite of nineteenth-century Santiago society, especially on topics such as fashion and within them hairdressing and grooming. This theme is revealed as a powerful source to deepen and evaluate the patterns of taste that united the dominant social group and its exhibitionist cares in a world of appearances.
\end{abstract}

Keywords: Modernity; Fashion; Privileged Social Groups; Santiago de Cuba City.

Recibido: $12 / 03 / 2020$

Evaluación: 17/06/2020

Aceptado: 19/09/2020

Anuario de la Escuela de Historia Virtual - Año 11 - No 18 - 2020: pp. 133-157.

ISSN: 1853-7049

http://revistas.unc.edu.ar/index.php/anuariohistoria 


\section{Peluquería y aseo: gusto francés y referentes de modernidad en el Santiago de Cuba decimonónico}

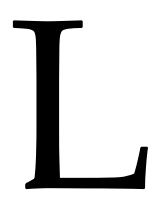

a preocupación por el buen vestir y por seguir las pautas dictadas por la moda extranjera se evidencian en Santiago de Cuba desde inicios del período colonial. Ya en el siglo XIX se hace ostensible no solo entre las clases de mayor solvencia económica, sino también en los estratos más pobres. Como bien acota el investigador cubano Ismael Sarmientos “(...) pervive en el cubano la distinción en el vestir: esto como un acto casi obligado dentro de las preocupaciones cotidianas, en las que poco se miden las limitaciones y las diferencias del poder económico del sujeto y se concentra el interés en la adquisición compulsiva de objetos de ostentación" (Sarmientos, 2004, p. 291).

Los patrones adoptados durante los siglos XVI al XVIII tuvieron que ver, en cierta medida, con la moda española acriollada por el clima. Con el advenimiento del siglo XIX se aprecia la asunción e interpretación de patrones franceses favorecidos, sobre todo en la región sur oriental, por la presencia de una pujante inmigración gala, asentada allí desde fines del siglo XVIII, luego de la Revolución de Saint Domingue (Haití). A partir de la tercera década de la centuria decimonovena, tal flujo migratorio, establecido fundamentalmente en Santiago de Cuba y su jurisdicción, se intensifica con individuos procedentes de la Francia continental. Los recién llegados, con un marco de referencia distinto del existente en la capital del Departamento Oriental, servirían como catalizadores del proceso de renovación de la sociedad y "transformarían en parte la infraestructura de la ciudad y sobre todo de su región cercana, trastocarían su vida cotidiana (...) y contribuirían (...) al desarrollo económico y al despertar social y cultural de esta zona, en lo adelante original, de la gran isla del Caribe" (Yacou, 1997, p. 74).

En estos arribos, directamente de Francia, se advierte la presencia de personas de diversas profesiones y oficios, quienes ofrecen una nueva dimensión socio-económica y cultural a la ciudad, que vio en estos hombres y mujeres no solo fuerza de trabajo calificada, sino también modernizadas formas de vida que contribuyeron a dinamizar las costumbres de la sociedad y la vida cotidiana del Santiago colonial. Su savia, el nuevo modelo de vida que irradiaron, las costumbres y modernas formas de comportamiento que aportaron como grupo humano a la vida local ha llevado a decir a Pérez de la Riva (2004, p. 105) que "solo la región oriental conservó una población francesa compacta y durable que impuso su lengua y modo de vida". Por su parte, el destacado intelectual José Antonio Portuondo (1993, p. 36) aseveraba que se impuso un “(...) ambiente de refinada cortesía (que) fue desbravando la parda adustez de la colonia y fue naciendo en el ánimo propicio del criollo una manera más alta de sensual 
refinamiento".

Los propósitos de los ilustrados santiagueros, de dejar atrás lo rural y establecer un diálogo con los signos del progreso llegados durante el siglo XIX desde Europa, no solo son perceptibles en el orden material, aunque este sea la parte más visible y perdurable de esos cambios, sino que se distinguen, además, en sus connotaciones espirituales. En Santiago de Cuba hubo también una intención de estar a tono con la modernidad a través de expresiones como la moda del vestir, los juegos, el lenguaje, las comidas, los temas de conversación y variados hábitos de urbanidad (Pepin, 1999).

Una sociedad moderna e ilustrada como la pretendida requería de una actitud ante la vida distinta de aquella que había caracterizado los comportamientos habituales. Entonces, la vida cotidiana local experimentó una renovación material y espiritual que se manifestó en los ámbitos público y privado; de igual manera, se incorporaron novedosos ceremoniales de sociabilidad que dieron al traste con el orden social sobre el cual había girado la conducta ciudadana hasta principios del siglo XIX. La nueva escenografía, al asumirse y ajustarse al contexto específico de Santiago de Cuba, armonizó con una praxis que cobró connotaciones simbólicas, y fue demostrativa de que se estaba abierto a transformaciones coyunturales, con apetencias cosmopolitas, aun cuando existieran lógicamente también algunas señales de inmovilismo y mezclas de rituales tradicionales con los modernos.

Esos hábitos expresan además las ansias de legitimación social de la elite, que no solo hizo del espacio privado un sitio de contacto social por excelencia, sino que asimiló nuevos ejemplos asociativos en las áreas públicas en consonancia con los ideales de progreso europeos. La evolución de esos comportamientos con el teatro, los paseos y las sociedades recreativas trajo como resultado una potente dinámica sociocultural que alcanzó su máximo esplendor hacia la década de 1850.

Tal situación no fue exclusiva de Cuba y de la ciudad de Santiago de Cuba. Los análisis sobre algunos países latinoamericanos, como Colombia, México, Argentina, Perú y Chile, evidencian que también sus sectores privilegiados adoptaron los referentes culturales galos, en tanto estos indicaban su pertenencia al progreso decimonónico. Eran patrones asumidos no solo como una moda, sino que se relacionaban con un trasfondo ideológico vinculado a los procesos de lucha por la independencia de España desarrollados en el continente americano, lo que permitía marcar entonces la diferencia entre la época de los virreinatos y la de los estados soberanos. En ese mismo orden, Haití no quedó a la zaga y durante el siglo XIX su elite de poder asume el modelo francés como sinónimo de refinamiento; según Denis (2007, p. 17) "la francofilia era toda una estética, un modo de vivir, una identificación intelectual, política y cultural con Francia".

\section{Un acercamiento al concepto de cultura material}

Para poder entender toda esa dinámica de la vida cotidiana o "cultura cotidiana" Anuario de la Escuela de Historia Virtual - Año 11 - No 18 - 2020: pp. 133-157. ISSN: 1853-7049 
136 | Peluquería y aseo: gusto francés...

(Burke, 2000, pp. 245-246) de una ciudad del Caribe insular hispano, "receptora" de la cultura francesa, en momentos en que cuajaban los conceptos, primero, de "patrilocalidad"1 y, luego, de "nacionalidad" y que en el siglo XIX eclosionaba hacia una nueva modernidad, se asumió como corpus metodológico los presupuestos de la historia de la cultura, defendidos por teóricos como Peter Burke, Clifford Geertz, Herve Carrier, Philippe Ariés y Roger Chartier. Bajo los mismos, se recurre desde hace varios años al estudio de la cultura para percibir los cambios económicos y sociales, que antes se analizaban de una forma reductora, y que insiste en tomar préstamos de la semiótica en función de distinguir símbolos, signos de una época, a través del estudio de las casas y sus habitaciones, el vestuario, la comida, el mobiliario, como traducción cultural del lenguaje del pasado al presente. Este punto de vista se extiende además en su enfoque al de cultura material y de la historia de las mentalidades, en tanto la primera, según Albuera (1998, p. 14) aproxima "a los aspectos tangibles de lo cotidiano", o como expresa Carrier (1994, p. 161) a la "concepción de la cultura que concede la primacía a las realidades materiales", es decir: comida, casa y vestuario, mientras la segunda va a lo abstracto, al nivel de pensamiento de los hombres y cómo influye el mismo en la transformación de los ámbitos públicos y privados. En tal sentido, el historiador cubano Zanetti (2002, p. 190) llama la atención sobre la pertinencia del estudio de la cultura material, ya que las “(...) influencias en materia de alimentación, vestuario, utensilios y tecnologías tienen un impacto sobre el modo de vida que probablemente supera en importancia social al influjo de ciertas manifestaciones del arte o la literatura".

Para los historiadores del arte, la cultura material significa otra cosa, en tanto se estudia un objeto dentro de su contexto ambiental y cultural, constituye entonces otro "documento" de análisis para entender una sociedad determinada como la economía y el consumo, el espacio privado o doméstico, la historia de los hábitos y costumbres relacionados con una concepción de cuerpo, la alimentación, la vivienda, el vestido y otras. De manera que:

(...) los objetos nos ayudan a pensar nuestro pasado desde la cotidianidad de lo material, lo cual puede ser una forma concreta de acercarnos a los modos en que distintos grupos sociales se pensaban a sí mismos y su entorno, para comprender la relación entre ideas y objetos, formas de pensar y de vivir, pues en los objetos se encuentra el sujeto en cuanto productor y consumidor de ideas (Ruiz, 2005, p. 7).

La historia cultural se ha interesado también por la materialidad, principalmente en objetos que son soporte de textos e imágenes, en tanto nos aportan información sobre los gustos, el estatus social, los imaginarios, las formas de vida, las trasformaciones materiales y espirituales, así como la apropiación que de ellos hicieron diferentes grupos sociales en el devenir de la humanidad. Para Colombres (2016) el objeto cobra

\footnotetext{
${ }^{1}$ Concepto dado por la doctora Olga Portuondo Zúñiga, historiadora de la ciudad de Santiago de Cuba.
} 
vida mediante los procesos de significación que el hombre entabla con ellos.

Con el objetivo de conocer esa realidad material que preocupó a los grupos privilegiados de Santiago de Cuba, la cual permite revelar el "contexto sociocultural e ideológico de la época" (Calderón, 1992), en tanto, los objetos decorativos y culturales son indicativos de los gustos artísticos e intelectuales, así como de las aspiraciones espirituales de sus poseedores (Manzanos, 2004), he querido internarme en la moda del vestir; en especial, en aspectos que cobraron una gran connotación, no solo dentro de los patrones de belleza y gustos estéticos, sino también en toda la simbólica que generaron: peluquería, barbería, objetos de aseo y maquillaje, así como en la perfumería en el lapso entre $1830-1868$.

\section{Santiago de Cuba: expansión comercial y protagonismo francés}

Santiago de Cuba, como ciudad puerto, tuvo durante los siglos XVII y XVIII un fuerte comercio de contrabando para el autoabastecimiento de la población. A mediados del siglo XVIII, y tomando como pretexto rivalidades entre Gran Bretaña y Francia, se incentivaron estas transacciones con el corso francés proveniente de Saint Domingue y otros puertos del Caribe como los de Jamaica. La dinámica comercial experimentada desde fines de ese siglo con la presencia de los criollos, inmigrantes catalanes y otros extranjeros, se favoreció desde inicios del XIX con las oleadas migratorias francesas, las que contribuyeron a incrementar los intercambios con los puertos de Burdeos, ${ }^{2}$ Marsella y El Havre y, ya en 1846, se inauguró la Compañía General Trasatlántica de Vapores Correos Franceses, de los cuales eran consignatarios en la capital oriental los señores Ducoureaux y Compañía. Desempeñaría un papel fundamental el puerto de Burdeos, lo que puede advertirse en la revisión del cotidiano bordelés L'Indicateur, donde se anunciaba, de igual modo, la partida hacia puerto santiaguero de estos mismos barcos.

Para Santiago de Cuba directamente, la bella nave de tres mástiles la Carolina de Burdeos, de 300 toneladas, de una marcha superior, partirá para su destino entre el 15 de marzo al 2 de abril próximo, bajo las órdenes del capitán Lamarque. Estando la mayor parte de su cargamento detenido, se tomaran aún como flete algunos pasajeros que serán tratados a su entera satisfacción. Dirigirse a M. Lestapis y compañía, Plaza Royale, No. $4 .^{3}$

La animación alcanzada por la ciudad con los buques que frecuentaban la bahía y la circunstancia de que su puerto era el centro hacia donde se dirigían muchos caminos de hierro, hicieron de Santiago de Cuba una de las más importantes poblaciones del Nuevo Continente. Era posible divisar en su rada "quince o veinte navíos (que)

\footnotetext{
${ }^{2}$ Similar a este proceso fue lo sucedido en algunos países de América del Sur, en especial Perú, donde los contactos comerciales eran fundamentalmente con el puerto de Burdeos, en tanto una gran parte de los migrantes hacia el Perú procedían del departamento de la Gironda.

${ }^{3}$ L'Indicateur, 4 de enero de 1832.
}

Anuario de la Escuela de Historia Virtual - Año 11 - No 18 - 2020: pp. 133-157. ISSN: 1853-7049 
duermen tranquilamente sobre el agua azul". Una ojeada a los números del periódico El Redactor entre 1830 y 1840, en su sección de entrada y salida de barcos, refrenda la presencia de muchos de ellos entre los que pueden mencionarse: Trois Frères, Paquete de Santiago, Paquete Bordelais, Guillermo Alexis, Albert Clemence, Caroline, Joven Eduardo, L' Irna. En la siguiente figura nótese la animación comercial del puerto.

\section{Figura 1. Plano de la ciudad de Santiago de Cuba}

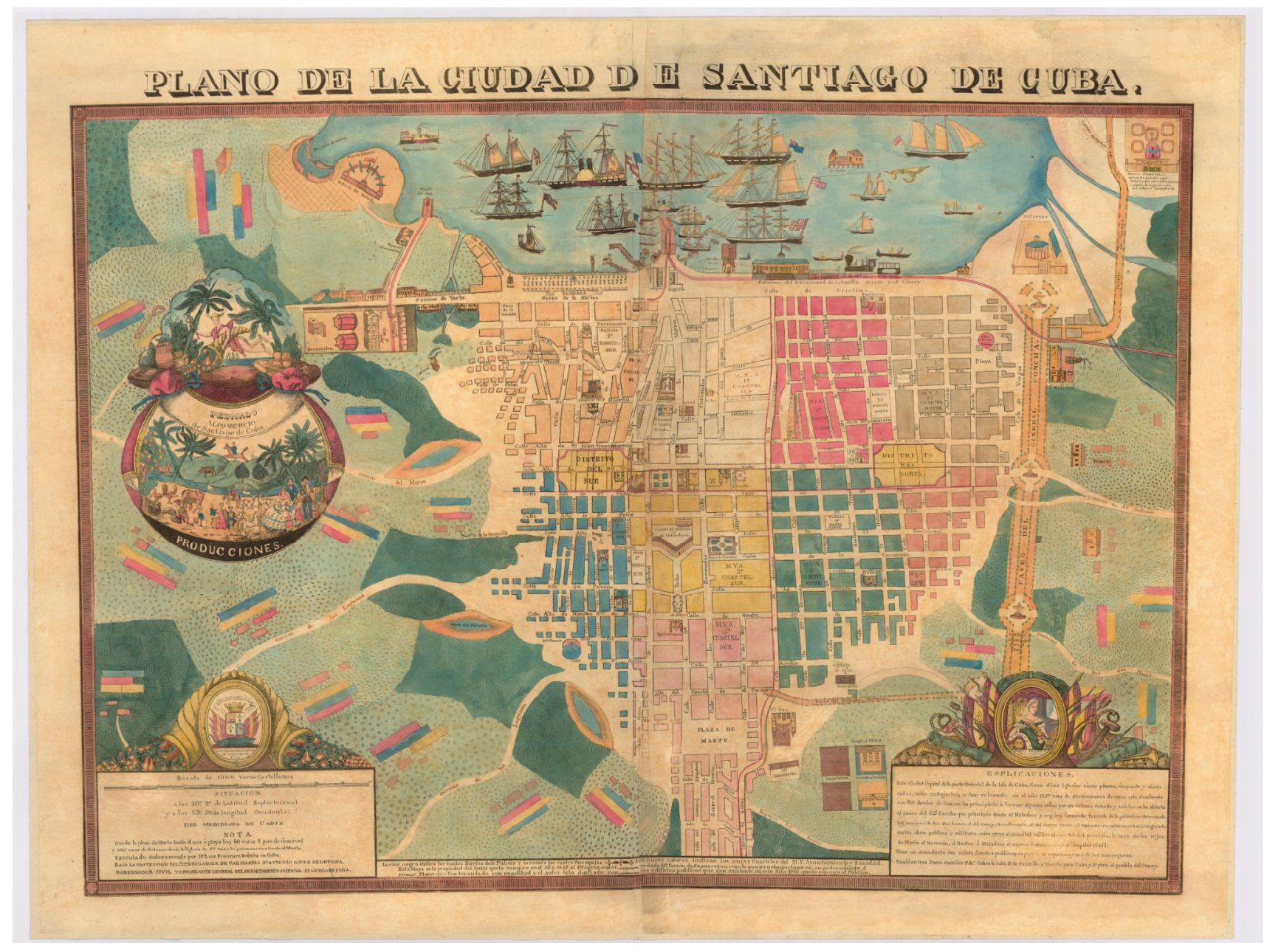

Fuente: Plano del autor Luis Francisco Delmés, 1861. Archivo personal de la autora.

De esta manera, se estableció un flujo-reflujo constante de mercancías: tejidos, vajillas, muebles, objetos decorativos, alimentos, vinos, joyas, calzado, confecciones, productos higiénicos; en fin, un amplio surtido que permitió al santiaguero modernizar sus costumbres. También llegaban hombres y mujeres con otros referentes culturales que contribuirían a transformar la vida cotidiana de la ciudad. Así lo refleja la prensa: “La hermosa y muy velera fragata francesa Deux Amis capitán Graveriau, saldrá para el puerto de Burdeos a principios del mes de febrero entrante, admite un resto de su 
cargamento a flete y pasajeros, a los cuales brinda el mejor trato posible (...) la despachan los señores Videau, Guignard y Cia". ${ }^{4}$

Ello contribuyó a consolidar una estructura comercial vinculada al incremento de la demanda de servicios especializados, donde se distingue una red de establecimientos y oficios vinculados a la moda, cuyos propietarios, por lo general, eran de origen francés o catalán, ${ }^{5}$ lo cual favoreció, en gran medida, el logro de una dinámica mercantil nunca antes vista por los santiagueros. Esta zona donde se mezclaban lenguas y colores, tuvo una importancia capital para la diversificación del comercio local. Dicha actividad le imprimió una dinámica muy peculiar y atrajo sobre sí la atención de comerciantes y pobladores. Un nutrido grupo de establecimientos fundados por los franceses en el siglo XIX quedaron insertados en esa franja baja cercana al puerto, que para 1822 albergaba más de 40 instalaciones comerciales regentadas por ellos, algunos naturalizados españoles y otros con su estatus de procedencia. La calle del Gallo se convirtió en una arteria bulliciosa que abría sus comercios desde horas tempranas de la mañana hasta la noche. Allí, acudían las damas de la parte alta de la ciudad a realizar las compras, haciéndose acompañar de sus hijas o sus sirvientas negras o mulatas.

(...) todo ese mundo de compradores y vendedores despierta con el día. Van y vienen, hablan y se callan. El aire está lleno de los ruidos del puerto, de las canciones de los negros, del azúcar que se rebaja, del café que se apila. Por todas partes y a todas horas, los negocios y los hombres de negocios pasan, ojean y siguen. En fin, uno se da cuenta de que está en una ciudad comercial y siente orgullo de pertenecer a Francia, al oír hablar solo francés allí donde se trabaja (Beauvallon, 2002, p. 253).

Inmersas en estos aires de bienandanza económica, se encontraron calles como San Francisco, Enramadas, Santo Tomás, San Juan Nepomuceno, constitutivas desde los inicios, del eje vertebrador del sistema urbano, y otras como Gallo y Factoría surgidas al calor del nuevo proceso de expansión verificado con la llegada y asentamiento de los franceses, estructuradoras del Barrio Francés, ubicado a la vera de la rada santiaguera. En ellas se concentraron la mayor cantidad de establecimientos dedicados a la venta de perfumería y otros productos de belleza, entre los que se destacaban: La Verdadera Sevillana, La Joven Cubana, La Elegancia Parisiense, La Isla de Cuba, El Buen Tono, Peluquería y Perfumería Francesa, La Elegancia, La Australia, El Eco de París y Londres.

Nótese que muchos de los nombres de las tiendas, peluquerías y otros

\footnotetext{
${ }^{4}$ L'Indicateur, 30 de marzo de 1836.

${ }^{5}$ El comercio local era dinamizado, entre otros, por los catalanes: Bartolomé Roig, José Fábregas, Mariano Mauri, Cristóbal Mestre, Antonio Vidal, Vicente Ferrer y Forgas, Tomás Torralbas, Magín Robert, Francisco Sarret y Rafael Cabé; italianos: Juan Piroya Modiny, Ubaldo Bottiglio y Vicente Fazzoli, Francisco Pau, Fernando Verdacci, José Antonetti y Angel Gallerino, así como por los franceses: Benjamín Pacaud, Dionisio Poirson, Carlos Bacarise, Juan Ducoureaux, Pedro Renau, Casamayor, Dufourg, Ducoureaux, Videau, Ribeaux, Caisean, Chevalier, Julien, Mollet, Gauriam, Fabiert, Auguste Arnoult. Hombres de sagacidad comercial y espíritu emprendedor, quienes supieron aprovechar muy bien el desarrollo económico de la región y los deseos de sus pobladores de modernizarse.
}

Anuario de la Escuela de Historia Virtual - Año 11 - Nº 18 - 2020: pp. 133-157. ISSN: 1853-7049 
140 | Peluquería y aseo: gusto francés...

establecimientos comerciales remiten a Francia como paradigma de los dictados de la moda. Resulta importante significar en este orden la labor promocional, que, ya entonces, realizaban los propietarios, comerciantes industriosos y perspicaces, quienes, tanto a nivel personal con los clientes que acudían al comercio, así como también a través de los anuncios insertados en el diario El Redactor, ponían de relieve la valía, calidad y origen de la mercancía que ofertaban. Este espacio para la publicidad resulta un ejemplo elocuente del poder de convocatoria de los anuncios de la época. Primero, se empleaba el texto, a fin de prodigar las bondades de los más disímiles productos y, para ello, se acudía a palabras claves que atraían a los posibles consumidores: novedad, calidad, elegancia, buen gusto, última moda y a frases como: "se está en relación directa con los mejores fabricantes de París" o "depósito constante de perfumería francesa". Resulta significativo el juego cómplice al que se entraba con el potencial cliente, pues, cada anuncio marcaba la procedencia francesa de esos artículos como sinónimo de modernidad y calidad. Un ejemplo ilustrativo es el siguiente anuncio, insertado en este rotativo local "(...) ya se halla este establecimiento nuevamente favorecido por un escojido (sic) y dilatado surtido de mercancías de París de las modas más recientes, importadas últimamente por la fragata francesa Carolina procedente de Burdeos". ${ }^{6}$ Igualmente, enfatizaban en París como "esa populosa capital, emporio siempre del buen gusto y la elegancia". ${ }^{7}$

Resulta revelador el proceso de identificación con ese mundo, pues, expresar en la prensa o en el vivir cotidiano el nombre de un artículo o prenda por su apelativo en francés era sinónimo de empaque social, de manera que muchos de los productos eran anunciados en la prensa en términos tales como: cenefas de Miguandise, mantas de filet de seda, enaguas a la dernier (a la última), encajes de Balenciens y de Chantilly, peinados a la girafe (jirafa), entre otros. En el siguiente anuncio nótese el empleo del idioma francés.

${ }^{6}$ El Redactor, 20 de diciembre de 1844, p. 3. El subrayado es de la autora (AMT).

${ }^{7}$ El Redactor, 20 de enero de 1859, p. 3.

Anuario de la Escuela de Historia Virtual - Año 11 - No 18 - 2020: pp. 133-157. ISSN: 1853-7049 
141 | Aida Liliana Morales Tejeda

Figura 2. Anuncio de establecimiento comercial insertado en el periódico local $E l$ Redactor

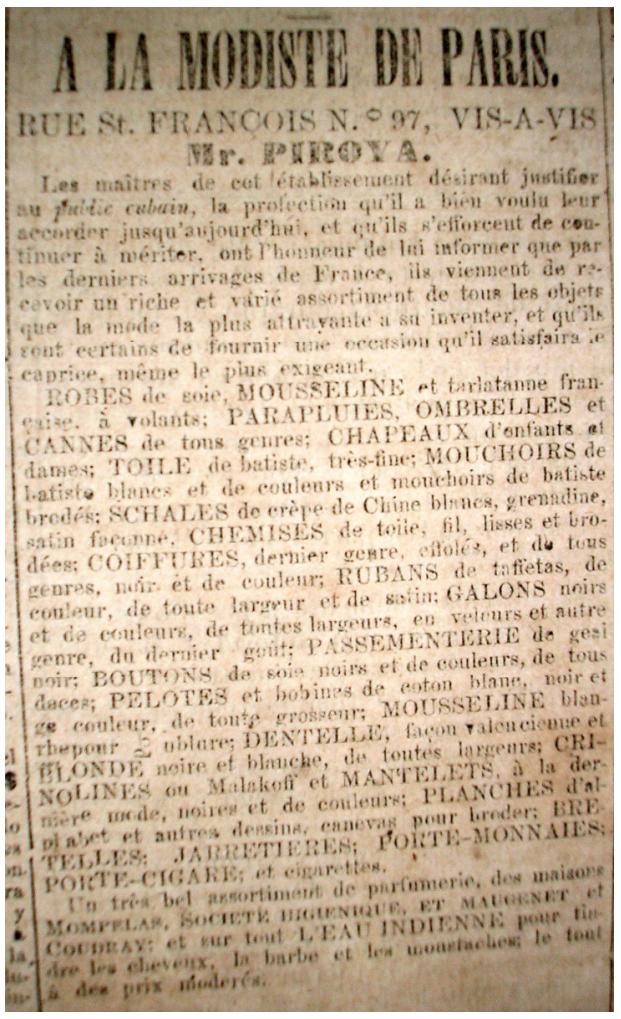

Fuente: El Redactor, 18 de marzo de 1858. Archivo personal de la autora.

Los libros de viajeros, como visión del otro, constituyen por sí mismos textos cuya lectura, además de amena y agradable, devela un sinnúmero de aristas. Completan la información sobre nuestros antepasados y sus costumbres. Han dejado escritos memorables acerca de la elegancia y el excelente gusto de la sociedad local, sobre todo de las damas, viajeros como el martiniqueño Hypolite Pirón, la norteamericana Caroline Wallace o el inglés Walter Goodman; este último, señala que:

(...) señoras y señoritas ataviadas con lindos vestidos de todos los tipos de muselina, y sin más tocado que el que generosamente les dio la naturaleza [...] hay mucho que admirar en las criollas más sencillas, sea que nos atraiga su gracioso andar, en lo que no hay mujer en parte alguna que las iguale, sea el buen gusto que manifiestan en el vestir, o el peinado de su rica cabellera (Goodman, 1996, pp. 136137).

Aun cuando los viajeros percibieran que el vestuario de la santiaguera era como el de la parisina, la moda seguida en Santiago de Cuba sufrió un proceso de adaptaciones que la identificaba y la distinguía de la importada. Si bien no puede hablarse de la existencia en aquellos momentos de una moda nacional, sí de un proceso de 
142 | Peluquería y aseo: gusto francés...

criollización acontecido a partir de la necesidad de adecuación del vestuario al clima y a las peculiaridades de la vida en la sociedad colonial.

Dos fueron las modificaciones esenciales: el uso del color y de materiales apropiados a las elevadas temperaturas tropicales. El primero tuvo que ver con la existencia mayoritaria de negros libres en los oficios vinculados a la moda del vestir, quienes contribuyeron a incorporar a las habituales gamas neutras provenientes de Europa el peculiar sentido del color propio de la cultura mestiza: llamativos rojos, amarillos y azules. Asimismo, en segundo lugar, estos hábiles hombres y mujeres supieron ingeniárselas para adaptar los figurines llegados desde París a las características del cálido clima cubano, cuando se cortaban mangas, ampliaban escotes o sustituían telas.

\section{El arte de la peluquería. De perfumes y cosméticos}

Hacia la cuarta década del siglo XIX se aprecia en la ciudad un creciente despliegue de artículos vinculados a la belleza personal, en particular el giro de la peluquería alcanzó gran popularidad y merecido prestigio, al radicarse en Santiago de Cuba un grupo importante de peluqueros (as) y barberos de origen francés, quienes insuflaron el buen gusto en el peinado, además de mantener informada a su clientela acerca de las maneras más modernas de llevar la cabellera y los productos necesarios para mantener su belleza e higiene. Este último aspecto formaba parte de las ideas de salubridad preconizadas desde el siglo XVIII, pero también de la moda. La adquisición y el disfrute, o no, de todos estos artefactos condicionaba la existencia de redes simbólicas que garantizaban un status dentro de la sociedad colonial, además de actuar como elementos transformadores o catalizadores de ciertas prácticas de la vida cotidiana.

Los censos y otros documentos permiten contabilizar la cantidad de establecimientos dedicados a este giro. El censo de $1846^{8}$ declara la existencia de 12 barberías, en donde trabajaban 74 barberos. Mientras, en 1862, se contaba con 35, donde laboraban 151 personas; entre tanto, se tenían 21 peluquerías. En ellos, se expendían objetos de uso doméstico, tales como estuches de navajas, asentadores, tijeras finas, cepillos de cabeza y de dientes; asimismo, podían adquirirse otros géneros más sofisticados para mejorar la apariencia y la higiene personal, en tanto, hasta fines del siglo XIX, resultaba difícil distinguir los límites entre cosméticos, perfumería, moda, peluquería y barbería, según expresa el reconocido perfumista francés Eugène Rimmel, en el volumen El libro de los perfumes.

Un reputado peluquero, que con frecuencia anunciaba las bondades de su oficio, era el francés Andrés Couturier, ${ }^{9}$ quien, desde su establecimiento situado en Enramadas

\footnotetext{
${ }^{8}$ Véanse los textos de Orozco Melgar (1994, pp. 176-177) y O’Donnell (1847, p. 225).

${ }_{9}^{9}$ Andrés Couturier fue peluquero de S. M. el Rey y de la Reina de Bélgica, de la Gran Ópera de Bruselas, de la Ópera Cómica, y de teatros del Ambigú y Luxemburgo de Paris. Por datos obtenidos en las Crónicas de Santiago de Cuba, suponemos que además de arreglar a las bellas santiagueras, también incursionaba en
} 
$\mathrm{N}^{\circ}$ 126, establecía las pautas de la moda del peinado; aunque se ofrecía a todo el público, tenía deferencia por las señoras, a fin de peinarlas con el mayor esmero; de igual forma, exponía en El Redactor “(...) efectos de curiosidad que no dejaran de agradar a las amables personas que quieran hacerle el honor de ir a visitar ese gran surtido que acaba de recibir de Paris, por los buques que han llegado últimamente de Francia". ${ }^{10}$

\section{Figura 3. Anuncio en la prensa del establecimiento de peluquería de Andrés Couturier}

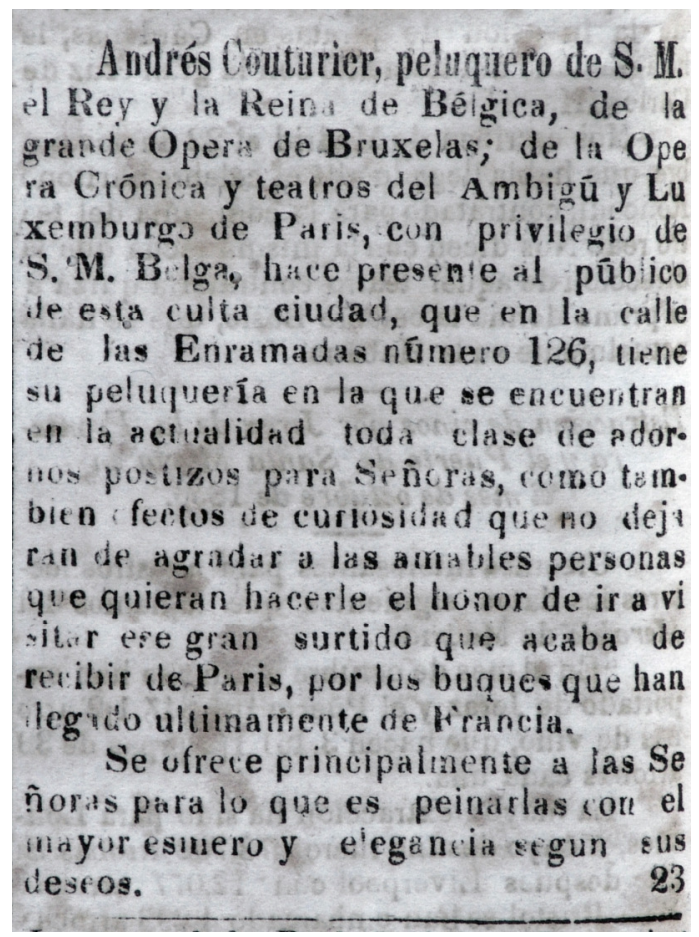

Fuente: El Redactor, 28 de agosto de 1848. Archivo personal de la autora.

Las mujeres santiagueras fueron amantes de exhibir sus cabellos con curiosas formas. Estos atributos fueron enaltecidos por Walter Goodman (1996), quien pudo admirarlas de cerca en todo su esplendor, pues, como pintor, tuvo como modelos a algunas jóvenes de la localidad, llamándole la atención el contraste de sus blancas pieles con las cabelleras oscuras y su capacidad de conservar el peinado todo el día, como si no hubiese sido tocado jamás. Este era adornado con flores naturales o artificiales en diferentes colores, cintas, pasadores, lazos de oro, plumas colocadas con donaire y turbantes egipcios, estos últimos puestos de moda durante el imperio napoleónico.

la escultura, ya que se le encargó realizar el vaciado en yeso del busto de la Reina Isabel II.

${ }^{10}$ El Redactor, 28 de agosto de 1848. 
144 | Peluquería y aseo: gusto francés...

La llegada de la moda neoclásica incidió en la forma de los peinados femeninos. Recrearon un ideal de belleza, vinculado a formas antiguas impuestas por la corte versallesca en los siglos XVII y XVIII. Se realizaban los llamados peinados a lo Luis XIV, a la Maintenon, ${ }^{11}$ a la Savigné, ${ }^{12}$ a la María Antonieta, a lo madame Récamier, ${ }^{13}$ a lo Ninon ${ }^{14}$ y a lo empolvado. Estas operaciones en el tocador constituían, sin dudas, la antesala para su brillo en los salones. En opinión de Ortego (2009, p. 14), esta:

(...) elaboración de una apariencia a la moda (...) dio origen a una operación semiprivada durante la cual las damas galantes podían revelar con coquetería fugaces visiones a algún admirador (...) será indicador del rango social, y el lugar donde las mujeres se esforzaban en cumplir con su obligación social de estar bellas, una idea de belleza que tendría que ver con lo gentil, grácil, bien formado, en porte y gestos.

\section{Figura 4. Modelos de peinado}

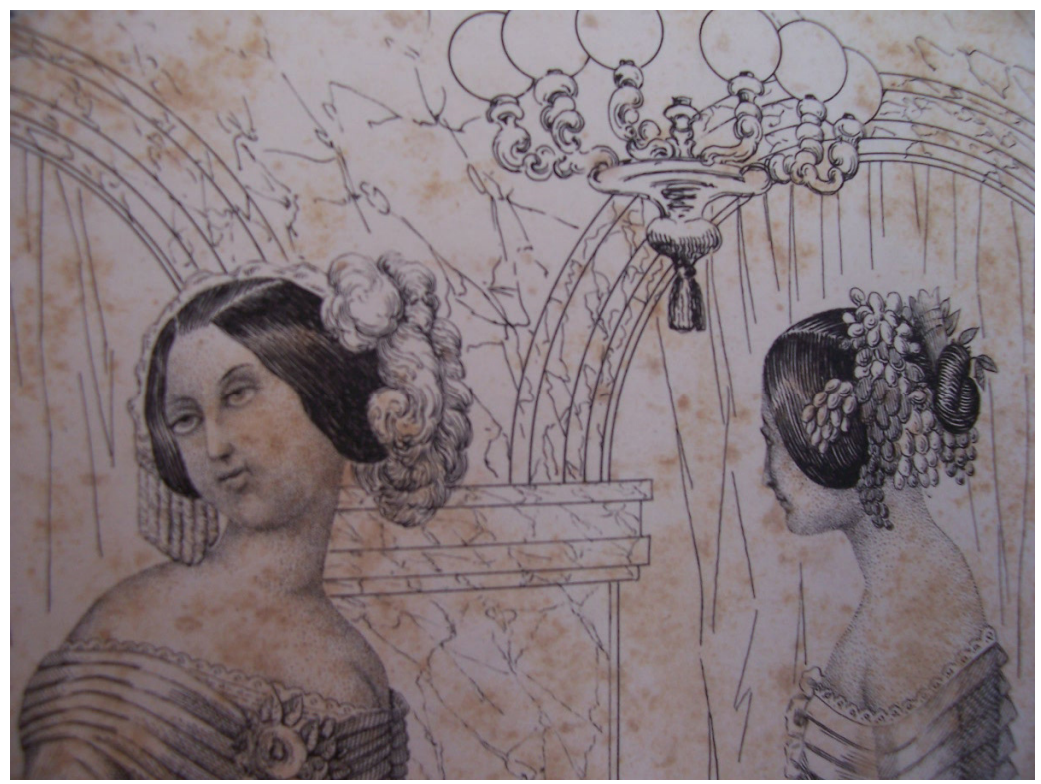

Fuente: Revista El Artista, 1846. Archivo personal de la autora.

\footnotetext{
${ }^{11}$ Françoise d'Aubigné, marquesa de Maintenon (1635-1719). En 1651, se casó con el novelista francés Paul Scarron. Tras la muerte de este en 1660, pasó a ser la institutriz del hijo ilegítimo de Luis XIV. En 1674 se convirtió en amante del Rey y se compró la finca de Maintenon, que pasó a ser un marquesado en 1678. A la muerte de María Teresa, reina de Francia, el rey se casó morganáticamente con ella. Conocida por su belleza e ingenio, fue considerada la figura principal de la corte francesa y ejerció sobre el Rey una gran influencia en asuntos religiosos y políticos. Su infancia humilde, la llevó a fundar la escuela de Saint-Cyr para las niñas pobres de familias nobles. Luego del fallecimiento del rey, pasó a un convento, donde murió.

${ }^{12}$ Marie de Rabutin-Chantal, casada a los 18 años con el marqués Henri de Sévigné, quien perdió la vida en un duelo. Murió a los 70 años a causa de la viruela. Es reconocida como escritora, y el epistolario con su hija, amigos y familiares, resulta un fiel testimonio de la vida en la corte y de la alta sociedad francesa en el siglo XVII.

${ }^{13}$ Jeanne Françoise Julie Adélaïde Récamier fue organizadora de un famoso salón literario en el París postrevolucionario y napoleónico.

${ }^{14}$ Anne “Ninón" de l'Enclos, fue una escritora, cortesana y mecenas de las artes francesa.
} 
En tanto los hombres se apuntaron al gusto por llevar bigotes negros copiosos, perilla a lo Napoleón III y cabellos cortos, portadores de connotaciones simbólicas vinculadas a las nuevas ideas propugnadas por la Revolución Francesa.

Para cumplimentar estas exigencias, eran recibidos desde París o Burdeos numerosos accesorios. Una de las casas comerciales de mayor renombre de la época, $L a$ Joven Cubana, propiedad de Mr. Adolfo Schottler, participaba a su clientela mediante el periódico local El Redactor, que había recibido de Burdeos un surtido para peluquería para confeccionar in situ trenzas, pelucas, casquetes para hombres, crespos, añadidos conocidos como castañas, rizos imitación natural para caballeros y señoras, tendencia no siempre bien recibida y que tuviera sus críticos desde las tribunas de periódicos y revistas.

Uno de los que reaccionó fue el periodista cubano Luis Victoriano Betancourt (1929, p. 212), quien alegaba:

(...) ninguno, en fin, de los peinados que se han usado desde principios de este siglo hasta hoy, por mujeres y hombres, y que dejaban siempre descubierta toda o la mayor parte de la frente de que se adornaban con ellos, pudo nunca superar en fealdad y ridiculez a esos disparates cabelludos, comprendidos bajo el nombre genérico de tupé, y que se llaman cerquillos, sortijas, ondulés, rizos, conchas, grifos y capules.

En droguerías, perfumerías y almacenes, se vendían variadas producciones francesas destinadas a la conservación, belleza e higiene de los cabellos. Estos productos tuvieron como destinatarios potenciales a los sectores privilegiados de la sociedad, pues, sus precios eran altos y se elevaban en dependencia de la calidad. A ello se sumaba la reputación del peluquero y la ubicación de su establecimiento en el entramado comercial.

Figura 5. Surtidos de objetos de peluquería en el establecimiento La Elegancia

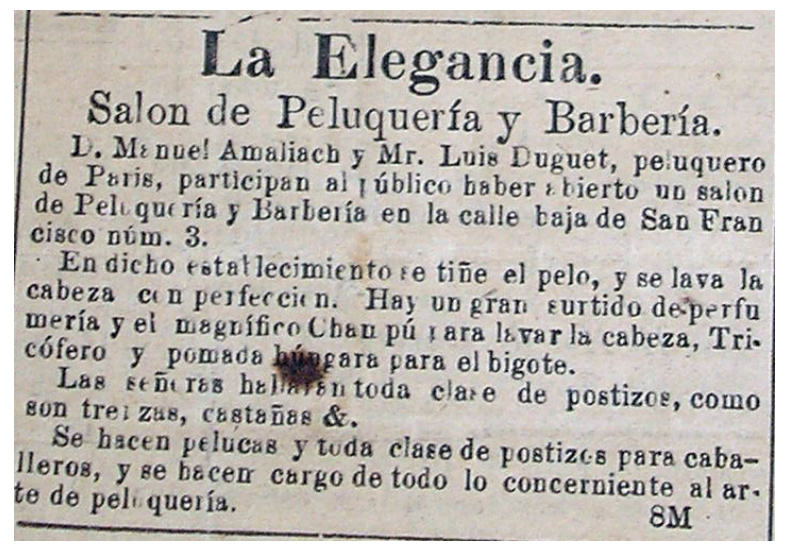

Fuente El Redactor, 3 de julio de 1850. Archivo personal de la autora. 
146 | Peluquería y aseo: gusto francés...

Entre los de mayor preferencia se comercializaban el Kathairon de Lyon, ${ }^{15}$ que se empleaba para "preservar, restaurar y embellecer los cabellos", y poseía cualidades para "hermosear, rizar el pelo, como medicamento para quitar la caspa y para producir nuevo pelo en cabezas calvas". ${ }^{16}$ Los peluqueros galos Leonard Lallier y Francisco Lechiere, ofrecían sus servicios en el establecimiento La Elegancia Parisiense, ubicado en la calle baja de San Francisco $N^{\circ} 3$, popularizaron entre los santiagueros de solvencia este producto. Existían además otros como el "Restaurador de pelo y Zilobálsamo o Domador Universal", de la señora S. A. Allen, utilizado en función de restablecer, vigorizar, hermosear y arreglar el pelo, volviéndolo sedoso, brillante y suave; el Tónico Oriental de Kemp, ${ }^{17}$ que consistía en un compuesto de sustancias vegetales recomendado para diferentes edades, sexos y todo tipo de cabellos, cuyas propiedades contribuían a fortificar el pelo, suavizarlo y darle un brillo natural, agradable e impedir su caída, evitar la caspa y que se criaran insectos.

Figura 6. Anuncio del Restaurador de pelo y Zilobálsamo

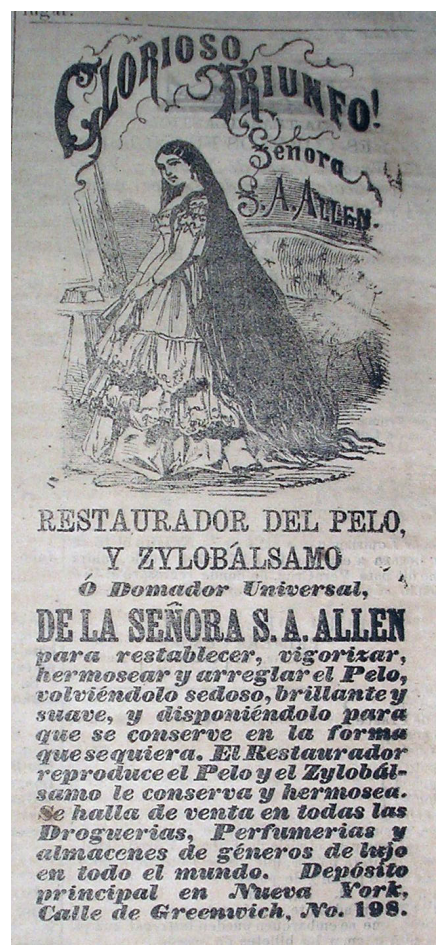

Fuente El Redactor, 23 de septiembre de 1860. Archivo personal de la autora.

\footnotetext{
${ }^{15}$ Fue introducido por el profesor E. Tomas Lyon de la Universidad de Princeton, Nueva Jersey, Estados Unidos.

${ }^{16}$ Estos anuncios aparecían durante días y, en ocasiones, hasta meses en el periódico local El Redactor, lo cual contribuía sin dudas a incrementar la clientela de estos peluqueros.

${ }^{17}$ Fabricado por los señores David Lanman and Kemp. Sus creadores y proveedores tenían su almacén en 69 Water St y los laboratorios en la 36 Gold St. y 6 Liberty St. en Nueva York.
}

Anuario de la Escuela de Historia Virtual - Año 11 - Nº 18 - 2020: pp. 133-157. ISSN: 1853-7049 


\section{Figura 7. Anuncio del Tónico Oriental}

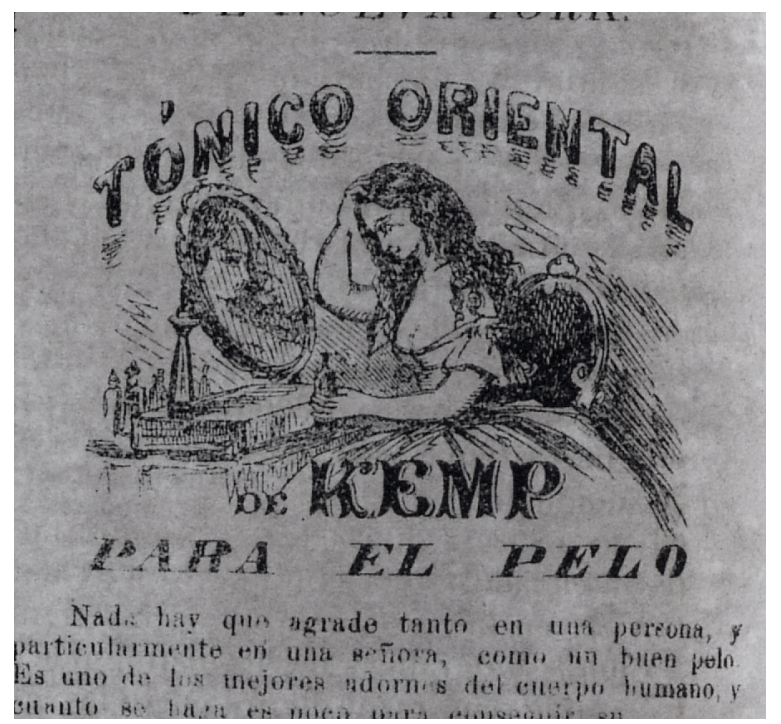

Fuente: El Redactor, 23 de septiembre de 1860. Archivo personal de la autora.

Al iniciar la sexta década del siglo XIX, aparece en las boticas y peluquerías un género que revolucionó el mundo de la peluquería y realzó la belleza femenina y masculina: el tinte de pelo, producción puesta a disposición del público en variados colores y gamas. Es curioso que la prensa local lo anunciara con naturalidad, si se toma en cuenta las convenciones de la época y de la sociedad santiaguera decimonónica; si bien, por un lado, los santiagueros gustaban de aparecer radiantes en público, por otro lado, no deseaban que se conocieran intimidades como la de teñirse el cabello, para cambiar el color o esconder las incipientes canas; importaban más las apariencias que la realidad.

Dichos productos fueron habituales en la red comercial y tuvieron una amplia publicidad, pródiga en alabanzas al describir sus beneficiosas propiedades. La tintura de Dicquenaire de Ruan, que obtuvo una medalla por la Sociedad de las Ciencias industriales de París, era exaltada como superior a todas las empleadas en esa época por su capacidad para "teñir en un minuto, en todos los matices, los cabellos y las canas, sin peligro para la piel y sin ningún olor". ${ }^{18}$ Por su parte, el tinte de Batchelor, era anunciado como el mejor del mundo y daba "un color que en nada se diferencia del natural y se garantiza que no causa daño alguno (...) antes al contrario, remedia los perniciosos efectos de los malos tintes, y da vigor al pelo para toda la vida".${ }^{19}$ Del tinte de José Cristadoro, se decía que era un "utilísimo invento, uno de los milagros del

\footnotetext{
${ }^{18}$ El Redactor, 1 de noviembre de 1866.

${ }^{19}$ El Redactor, 12 de febrero de 1860.
} 
presente siglo y no tiene rival en el mundo". ${ }^{20}$ De igual manera, la tintura inglesa instantánea era recomendada como la mejor preparación para teñir el pelo y la barba; mientras, el Extracto Regenerador de Mil Flores, era un champú empleado para la limpieza tanto del pelo como de la piel, pues refrescaba, quitaba el dolor de cabeza y la presión del espíritu.

Figura 8. Anuncio del tinte de Batchelor

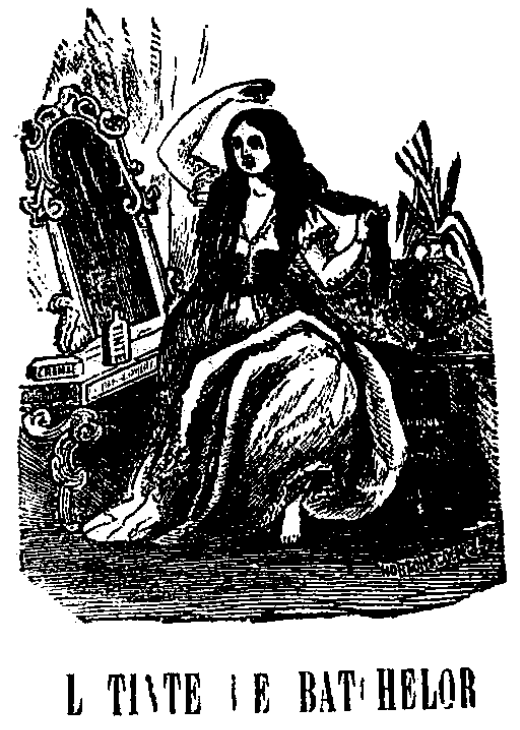

ES EL MEJOR del MUNDO.

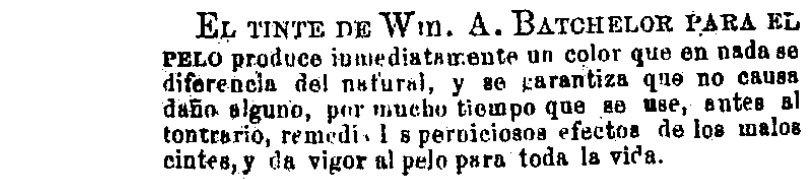

Fuente: El Redactor, 12 de febrero de 1860. Archivo personal de la autora.

\section{El aseo y la higiene personal}

Un aspecto al que siempre se le prestó atención fue la higiene personal. Un complemento importante en todo este proceso fueron los perfumes, polvos, y odorantes, los cuales, desde el siglo XVII, adquirieron una nueva dimensión, pues estos cosméticos actuaban como limpiadores del cuerpo, en una época en que el agua aún no era vista como parte de las necesidades de aseo del ser humano (Soto, 2009).

Si las mentes ilustradas propugnaban la limpieza e higiene de las ciudades, también buscaban las del hombre para luchar contra las enfermedades y epidemias que diezmaban las poblaciones. Este proceso culminó en occidente durante el siglo XIX, cuando "la higiene irrumpe como una rama de la medicina encargada de la

\footnotetext{
${ }^{20}$ El Redactor, 12 de febrero de 1860.
} 
conservación y mantenimiento del cuerpo. Después de un largo proceso de regulación de sensaciones corporales, la limpieza se sistematiza y se institucionaliza a través de la higiene. Lo importante de este fenómeno es que ayuda a entender cómo surge ese esmero en el cuidado de sí mismo" (Costilla, 2016, p. 19). Por su parte, Soto Roland (2009, p. 5) indica que hasta el siglo XIX, el baño no fue tomado en Francia como una necesidad, en tanto ser limpio no necesariamente implicaba el uso del agua para el cuerpo, pues, perfumes, polvos y pelucas odorantes alcanzaban una importancia significativa; y, con ellos, la ilusión se complejiza debido a que estos elementos cosméticos actúan como limpiadores, a la vez que corrigen el aire corrompido, preservando al hombre del contagio de la peste.

Los investigadores del tema afirman que este fue otro aspecto tomado por la burguesía europea, que veía en el uso del baño de agua caliente cierto afeminamiento, artificio y haraganería aristocrática. En Cuba, en tanto, el aseo corporal constituyó costumbre entre todas las capas de la población, para luchar contra las inclemencias del clima tropical y marcó nuevos ritmos cotidianos, pues el cuidado del cuerpo requería tiempo y un nuevo ritual en la intimidad (Bermúdez y Urbano, 2001).

Figura 9. Anuncio de una casa de baños

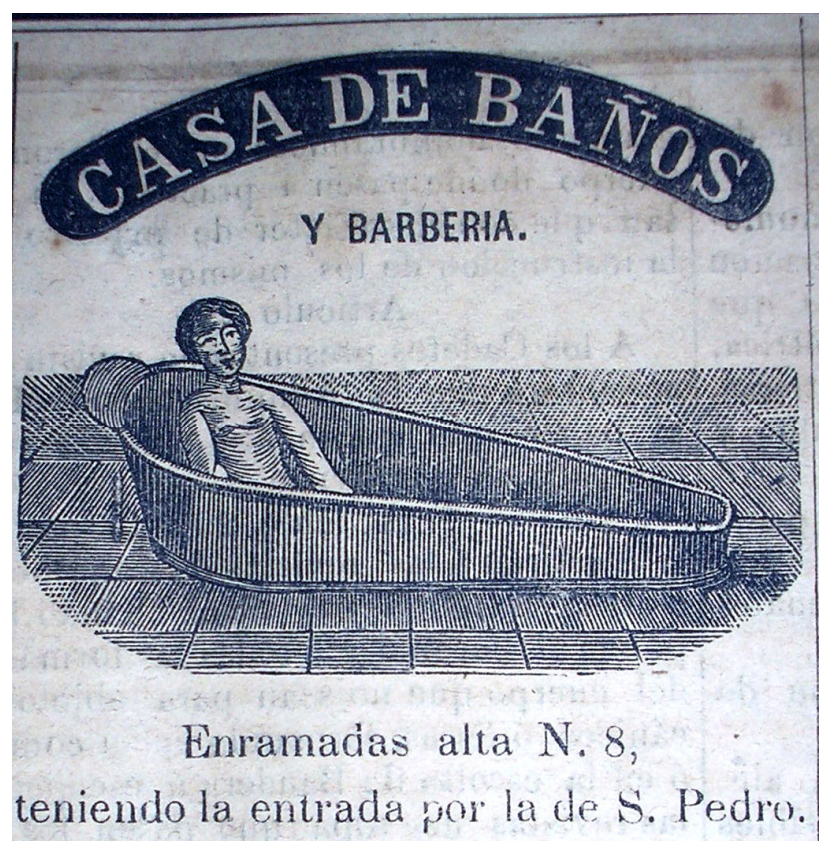

Fuente: El Redactor, 22 de noviembre de 1861. Archivo personal de la autora.

El viajero inglés Walter Goodman, quien permaneció cinco años como residente en Santiago de Cuba, pudo conocer a fondo las características de la vida cotidiana local. En su obra Un artista en Cuba contrasta el empleo del agua tibia o caliente entre los habitantes de la ciudad capital del Departamento Oriental de Cuba, a contrapelo de lo 
150 | Peluquería y aseo: gusto francés...

que dictaban entonces los tratados y normas de higiene, que inducían a tomar baños de agua fría por sus virtudes estimulantes y morales, según los médicos enciclopedistas. Según Goodman (1996, p. 24):

De una a tres de la tarde, don Benigno y su familia disfrutan del saludable lujo de un baño caliente, pues, a despecho del clima, el criollo cuando se halla en la ciudad, rara vez se sumerge el cuerpo en agua enteramente fría. El agua que ha de usarse en el baño se pone en el centro del patio para que el Sol la caliente hasta un grado razonable de temperatura.

Así en la casa burguesa se implantó el cuarto de baño como espacio independiente del resto de las habitaciones. Se daba justamente una disposición a la tina y los aguamaniles. Fue Armand-Claude Mollet, quien, en el hotel d'Evreux, actual palacio del Elíseo, situó el baño en las proximidades de los dormitorios y no junto a la cocina, como era costumbre hasta entonces. En efecto, fueron muy destacadas las mejoras introducidas en materia de higiene. Aumentó el número de cuartos de baño, y también el de los cabinets de toilette (tocadores) y de los depósitos de agua, se adoptó asimismo el excusado "a la inglesa", con una válvula para combatir los malos olores. Por vez primera, de modo generalizado, se asociaba la limpieza de la piel humana con un espacio doméstico específico, aunque este quedaba limitado a las clases prominentes de la sociedad. Así, según Vigarello (1991, p. 233) “el espacio burgués de mediados de siglo ha ido conquistando primero lo que las muy grandes moradas habían conquistado en la primera mitad del siglo XVIII: lugares íntimos en los que el aseo y las abluciones parciales poseen sus espacios particulares".

Relacionados con ese mundo de abluciones diarias, estuvieron presentes también los anhelos de actualidad y bienestar, por lo cual, eran importados desde Europa, fundamentalmente desde los puertos franceses, numerosos objetos que coexistían con otros de confección local, que daban respuesta a esas exigencias y nuevas prácticas. Así, desde las páginas del periódico local El Redactor, los propietarios del establecimiento comercial "El Nuevo Mundo" promovían que "por el bergantín Louis de Burdeos, se han recibido gran cantidad de efectos (...) ricos juegos de aposento, orinales con su tapa, escupideras, palanganas y jaboneras de fina porcelana decorada y juegos de aposento de porcelana y cristal". ${ }^{21}$ Todos rivalizaban en calidad y buen gusto $\mathrm{y}$ eran confeccionados en plata, maderas preciosas y cristales con esmeradas terminaciones que hoy se admiran por su belleza y contrastan con los menesteres a los que estaban dedicados.

\section{Géneros para la limpieza del cuerpo}

En ese ámbito, la toilette, en especial la femenina, constituyó todo un ritual que, aun

${ }^{21}$ El Redactor, 7 de enero de 1859.

Anuario de la Escuela de Historia Virtual - Año 11 - No 18 - 2020: pp. 133-157. ISSN: 1853-7049 
cuando poseía carácter íntimo, formaba parte también de los alardes de representación social de las mujeres santiagueras de la época. Los relatos de viajeros y la prensa local, refieren el apego de los santiagueros al consumo de productos necesarios para la higiene personal, expendidos en establecimientos especializados en perfumería y también en las boticas, lo que indica que estos eran concebidos como parte de las ofertas para mantener la salud; por ello, se insertaban notas donde ponderaban algunos con propiedades curativas, cuyos compuestos esenciales provenían de plantas con cualidades para atenuar diversas afecciones y dolencias. Como ejemplo, se encuentra el del Agua de Verbena o yerba Luisa, de Jules Hauel y $\mathrm{C}^{\circ}$, con efectos tónicos y refrescantes, que quitaba el dolor de cabeza y cauterizaba las cortaduras, por lo que se recomendada tanto para el baño como para el tocador, sobre todo de las personas que sufrían de trastornos nerviosos.

Entre las décadas de los treinta y los sesenta del siglo XIX, los principales exportadores hacia Santiago de Cuba fueron la Sociedad Higiénica de París y la Sociedad Hagnofile; los fabricantes Lubin, Regnier, Piver, Mampelas, Maugenet, Coudrai, Pierre y Ed. Pinaud, que contaban con corresponsales en Londres, Nueva York, Barcelona, Bremen y Hamburgo y La Habana; en Santiago de Cuba, tiendas como La Australia, El Palo Gordo, La Isla de Cuba o El Gran Bazar, servían como depositarias de estas casas. Estos productos de perfumería, en criterio de Costilla (2016, p. 62):

(...) devinieron objetos de consumo industrializados que funcionaban bajo una lógica de mercado globalizada responsable de añadir ideales al proceso de compra. Es decir, cuando se adquiría una crema, polvo o jabón, no se estaba obteniendo, únicamente, una serie de promesas respecto a la modificación del cuerpo, sino que también, se compraban valores de la modernidad.

Uno de los productos que ganó gran aceptación fue el jabón, que “dejó de ser un simple cosmético destinado a fomentar la coquetería, para convertirse en la principal herramienta de la salud y la higiene, por su capacidad para deterger la piel de la grasa y de los microbios" (Costilla, 2016, p. 196). Se expendían jabones provenientes de las mejores fábricas de Europa, dirigidos a toda la familia, entre los que se encontraban: de lechuga, ambarino, caramelo, emperatriz, alcanforados, de Windsor, de Abelina, Guinanue, flor de Italia, Tridace y el Demarson. Este último, por sus propiedades tónicas, era muy utilizado por mujeres y niños en el cuidado de sus pieles, que también recibían el beneficio de cremas y pomadas de olores agradables como el páte d'amandes (crema de almendras), pudre de riz (polvo de arroz), cold cream (crema fría), para suavizar y mantener la frescura del cutis, que se ponderó como el espacio privilegiado de acción de todos los afeites. También se adquirían pomadas y aceitillos de plantas como la Tubereuse, Resedá, Geranium, vainilla blanca, con el fin de conservar la tersura de la piel y eliminar pecas o manchas producidas por el sol.

La higiene bucal se mantenía con polvos y elíxires de la Sociedad Higiénica y de Nuguet, elixir odontológico Eau des Cordelieres, “un dentífrico superior que prevenía las 
152 | Peluquería y aseo: gusto francés...

caries, curaba el dolor de muelas y mejoraba el aliento", ${ }^{22}$ agua dentífrica del Doctor

Pierre. Todos eran despachados en pequeños envases de cerámica esmaltada en colores verde, blanco y amarillo, de los cuales se han encontrado evidencias arqueológicas.

Figura 10. Polvos para la dentadura

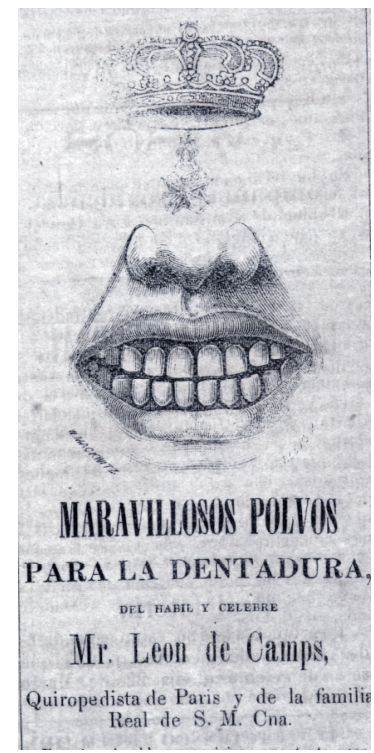

Fuente: El Redactor, 8 de febrero de 1860. Archivo personal de la autora.

\section{Figura 11. Sozodonte para los dientes}

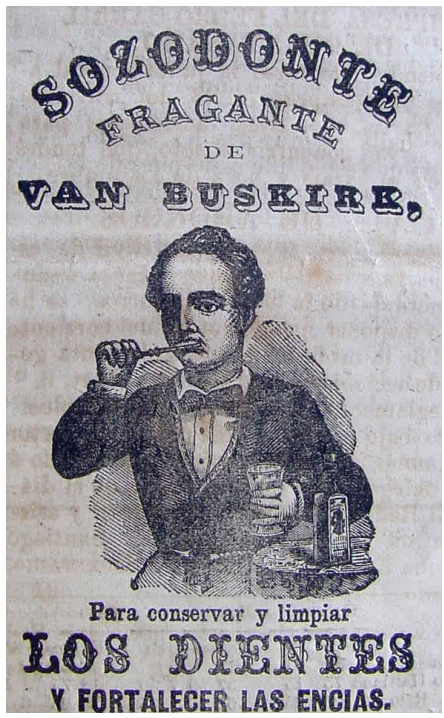

Fuente: El Redactor, 20 de julio de 1859. Archivo personal de la autora.

${ }^{22}$ El Redactor, 20 de julio de 1859.

Anuario de la Escuela de Historia Virtual - Año 11 - Nº 18 - 2020: pp. 133-157. ISSN: 1853-7049 
Figura 12. Potes para guardar polvos higiénicos

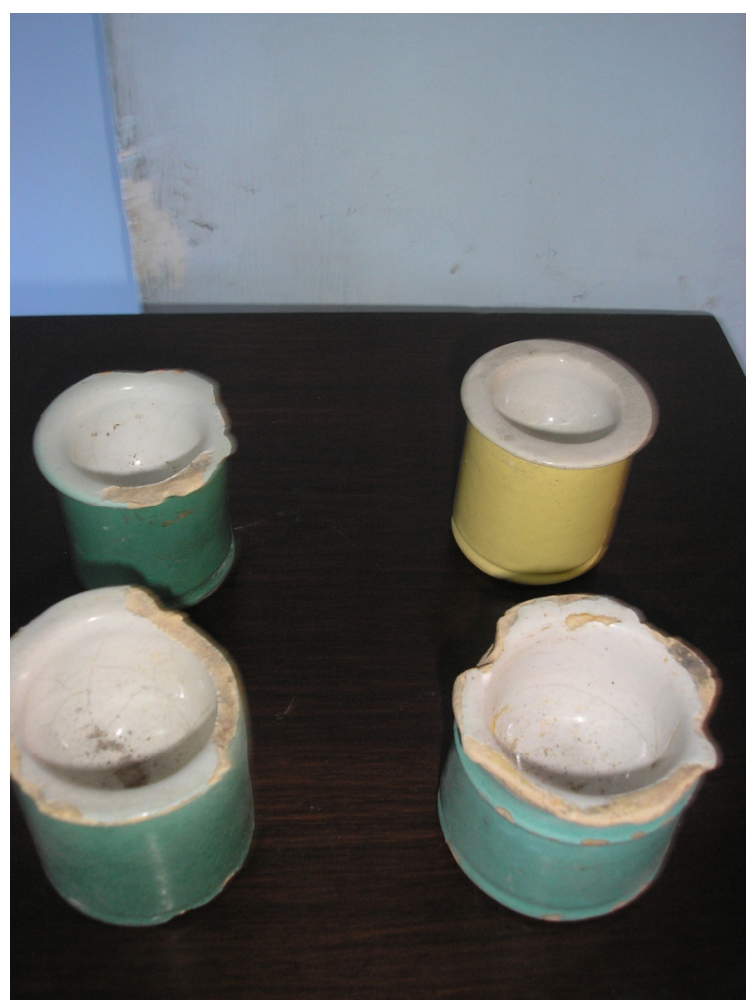

Fuente: Colección Gabinete de Arqueología Oficina del Conservador de la Ciudad. Santiago de Cuba.

En tanto, la perfumería fue bien atendida y, aunque los viajeros comentaron poco sobre el particular, se considera que los santiagueros sí conocían los secretos del uso de las fragancias en el baño, el pañuelo, los guantes, el abanico, medallas, cajas, canastas y el cuerpo. Prácticamente cualquier objeto o entorno podía ser aromatizado. El perfume, en realidad, desempeñaba las funciones de limpieza, purificación y seducción del olfato. Su uso sobrepasaba el hecho de ser una práctica estética debido a que sus funciones abarcaban tanto la asepsia como la terapéutica (Costilla, 2016).

De tal forma, el ambiente que se respiraba era agradable durante el día y en las fiestas o el teatro. Se expendían las eau de toilettes (aguas de colonias) y extractos como el Agua del Celeste Imperio: "este es el perfume más esquisito (sic) y agradable para el tocador y para el pañuelo"; colonia de Jean Marie Farina, de Mampelas, Doble, Agua Florida, Agua Lavanda, elixir de Pierre y Pelletier y Agua Ateniense, Bouquet de la Emperatriz, que era un perfume rico, suave, duradero y actuaba como signo de distinción femenina. Todos ellos eran envasados en frascos de cristal, porcelana y otros materiales, con diseños atractivos y estéticos que se convertían en un objeto decorativo, colocados sobre las encimeras y las coquetas. Entre los de mayor reconocimiento estuvieron los perfumes provenientes de la firma Lubin: 
154 | Peluquería y aseo: gusto francés...

(...) cuyo éxito cobró impulso desde que la Emperatriz Josefina, y Paulina Bonaparte, se hicieron clientas recurrentes de las creaciones de esta casa de perfumes. La época napoleónica permitió que esta marca se consolidara como un símbolo de estatus social y de refinamiento cultural por la aceptación que había logrado dentro de la aristocracia (Costilla, 2016, p. 62).

La calidad de los productos era equiparada a los que empleaban las casas reales europeas "los perfumes más suaves, mejor preparados y que más a la moda están en la alta sociedad, son hoy en día los que salen de la casa tan conocida L. Legrad perfumista, proveedor de las cortes de Francia, Rusia e Italia. 207 rue St Honoré en París. Se compran en todas las casas de venta de perfumería de la Habana y de la Isla de Cuba". ${ }^{3}$ Los perfumes resultaron bastante asequibles a distintas capas de la sociedad santiaguera. Sus precios oscilaban entre sesenta y setenta centavos el frasco, hasta \$ 6.00 la docena. Solo en el año 1859, se contabilizaba la venta de más de 20.000 docenas.

Ocupó lugar preferente dentro de los cosméticos y afeites la conocida cascarilla, ${ }^{24}$ usada por las féminas de todos los colores y sin distinción de clases, para el blanqueamiento del cutis, el cuello y la espalda; esta se diferenciaba del polvo de arroz que las parisinas se untaban en sus rostros y les dejaba un rastro mate, de lo cual dejó constancia Hippolyte Piron quien contrasta el carácter de la tez de la mujer cubana y su belleza con respecto a la parisina que se blanqueaba con polvo de arroz:

En la piel suave y perfumada de sus espaldas bien formadas, que los vestidos escotados dejan ver, no se encuentra el trazo mate que siempre deja el polvo de arroz. Ellas reemplazan este afeite, que se pretende sea indispensable en el atavío de las parisinas con la cascarilla elaborada en el país (Piron, 1995, p. 79).

Este cosmético provenía de dos materiales: cáscara de huevos y conchas o caracolillos, que se trituraban hasta convertirlos en polvo; y, aunque poco se diferenciaban, nuestras coterráneas de entonces preferían las obtenidas de los caracolillos, porque tenían mayor poder de blancura y de adherirse al cutis donde era aplicado con generosidad, como bien lo describe la viajera norteamericana Caroline Wallace. Ello llevó a más de un picante periodista a emplear su pluma para atacar su desmedido uso; José Joaquín Hernández, en el artículo costumbrista "La cascarilla", en sus Ensayos Literarios satirizó tal proceder, al exponer que durante los bailes las cubanas desteñían, y los jóvenes la llamaban mancha casacas. Era este un ideal estético que pesaba sobre el cuerpo femenino, que era entendido como una especie de juguete delicado que debía mantener un permanente aspecto juvenil (Ortego, 2009, p. 14).

${ }^{23}$ El Redactor, 20 de julio de 1860.

${ }^{24}$ La cascarilla se obtenía a partir de triturar las cáscaras de huevos y también se empleaban los caracoles.

Anuario de la Escuela de Historia Virtual - Año 11 - No 18 - 2020: pp. 133-157. ISSN: 1853-7049 


\section{Conclusiones}

Como se ha podido apreciar, los propósitos de los grupos de elite de Santiago de Cuba al dejar atrás lo rural y establecer un diálogo con los signos del progreso llegados durante el siglo XIX desde Europa no solo son perceptibles en el orden material, aunque este sea la parte más visible y perdurable de esos cambios, sino que se distinguen, además, en sus connotaciones espirituales. De esa manera, se hizo patente una intención de estar a tono con la modernidad a través de expresiones como los hábitos de urbanidad, los juegos, el lenguaje, las comidas, y, el caso que nos ha ocupado, en la moda y todo lo relacionado con ella: perfumería, peluquería, barbería, objetos de aseo y maquillaje.

Esta se revela como una poderosa fuente para profundizar en la vida de la sociedad santiaguera decimonónica, evaluar los patrones del gusto de la elite y entender los signos distintivos de una estética que tomó como paradigma a Francia, país que desde el siglo XVIII dictaba las pautas de la suprema elegancia y las extendía por toda Europa, incluida España, llegando por esa vía a América con bastante rapidez.

\section{Referencias bibliográficas}

Åke Alvarsson, J. (2012). Belleza y Utilidad. La cultura material. Villa Montes: Universidad de Uppsala en cooperación con FI'WEN.

Albuera Guirnaldos, A. (1998). Vida cotidiana en Málaga a fines del siglo XIX. Granada: Editorial Ágora.

Antón Dayas, I. (2016). Cultura material y formas de vida cotidiana de la sociedad burguesa alicantina en la España de la Restauración (Tesis de doctorado). Facultad de Letras, Universidad de Murcia, España.

Beauvallon, J. B. R. (2002). La Isla de Cuba. Santiago de Cuba: Editorial Oriente.

Betancourt, L. V. (1929). Artículos de costumbres. La Habana: Cultural S. A.

Bermúdez, S. y Urbano, D. (2001). Los espacios en los hogares de la élite santafereña en el siglo XIX, desde una perspectiva de género. Historia Crítica, 19. Recuperado de http://historiacritica.uniandes.edu.co/view.php/428/l.php (Fecha de descarga 3/06/2019).

Burke, P. (2000). Formas de historia cultural. Madrid: Alianza Editorial.

Calderón, C. (1992). Mujeres, ideología y cotidianidad en la Galicia de mediados del siglo XVI. Un estudio de caso: el testamento e inventario de bienes de la condesa de Altamira, doña Ana de Toledo. Revista de Historia, 3, 107-128.

Carrier, H. (1994). Diccionario de la cultura. Navarra: Ed. Verbo Divino.

Colombres, A. (2016). Poética de lo sagrado. Una introducción a la Antropología simbólica. La Habana: Ediciones ICAIC.

Costilla Leyva, C. (2016). Belleza e higiene. La publicidad de productos para la piel en El Mundo Ilustrado, 1895-1908, tesis de Maestría en Historia Moderna y Contemporánea, Instituto de Investigaciones José Luis Mora, México. (Fecha de descarga: 14 de julio de 2020)

Denis, W. R. (2007). Orígenes y manifestaciones de la francofilia haitiana: nacionalismo 
156 | Peluquería y aseo: gusto francés...

y política exterior en Haití (1880-1915). Secuencia, 67, 93-139.

García Fernández, M. (2016). Cambios y permanencias en la cultura material cotidiana no privilegiada: un mundo complejo. Castilla (y Portugal) a finales del Antiguo Régimen. Revista Historia (São Paulo), 175, 173-202. Recuperado de http://dx.doi.org/10.11606/issn.2316-9141.rh.2016.124070 (Fecha de descarga 6/6/2019).

Goodman, W. (1986). Un artista en Cuba. La Habana: Editorial Letras Cubanas.

Juárez Méndez, N. P. (2019). Historia de la cultura material: los bienes de una familia del siglo XVII en Parral. Debates por la Historia, VII (2), 85-117.

Manzanos Arreal, P. (2004). La casa y la vida material en el hogar. Diferencias sociales y niveles de vida en las ciudades vascas del Antiguo Régimen (Vitoria, siglos XVIII). En J. M. Imízcoz Beunza (Ed.), Casa, familia y Sociedad. (País Vasco, España y América, siglos XV-XIX) (pp. 51-78). Bilbao: Universidad del País Vasco/Euskal Herriko Unibertsitatea.

O’Donnell, L. (1847). Cuadro estadístico de la siempre fiel Isla de Cuba, correspondiente al año de 1846, formado bajo la dirección y protección del Escmo Sr. Gobernador y Capitán General Leopoldo O' Donnell. La Habana: Imprenta del Gobierno y Capitanía General.

Orozco Melgar, M. E. (1994). La desruralización en Santiago de Cuba: génesis de una ciudad moderna. t. II (Tesis de Doctorado). Facultad de Artes y Letras, Universidad de Oriente, Santiago de Cuba.

Ortego Agustín, M. A. (2009). Discursos y prácticas sobre el cuerpo y la higiene en la Edad Moderna. Cuadernos de Historia Moderna Anejos, VIII, 67-92.

Pérez de la Riva, J. (2004). La conquista del espacio cubano. La Habana: Fundación Fernando Ortiz.

Piron, H. (1995). La Isla de Cuba. Santiago de Cuba: Editorial Oriente.

Pépin Lehalleur, M. (1999). Entre ruralidad y urbanidad, la fuerza del lugar. En A. P. de Teresa y C. Cortés Ruiz (Coords.), La nueva relación campo-ciudad y la pobreza rural (pp. 69-84). México: Plaza y Valdés Editores.

Portuondo Valdor, J. A. (1993). Presencia francesa en el Oriente cubano. En J. Lamore (Coord.), Les français dans $l^{\prime}$ Orient Cubain. Maison de Pays Ibériques (pp. 31-46). Santiago de Cuba/Bordeaux: Universidad de Oriente, Université Michel de Montaigne-Bordeaux III.

Ruiz Valdés, J. del R. (2005). Cultura material y sociedad colonial: un estudio desde documentos notariales. Santiago 1690-1750 (Tesis de Licenciatura en Historia). Facultad de Filosofía y Humanidades, Departamento de Ciencias Históricas, Universidad de Chile, Santiago de Chile.

Sánchez Climent, A. (2018). El señor de las cosas: una síntesis sobre el artefacto y la cultura material en la arqueología. Vínculos de Historia, 7, 134-156. Recuperado de http://dx.doi.org/10.18239/vdh_2018.07.08 (Fecha de descarga 6/7/2020).

Sarmientos Ramírez, I. (2004). Cuba entre la opulencia y la pobreza. Población, economía y cultura material en los primeros 68 años del siglo XIX. Madrid: Agualarda Editores.

Soto Roland, F. J. (2009). La limpieza en la historia. Recuperado de http://letrasuruguay.espaciolatino.com/aaa/soto_fernando/la_limpieza_en_la_historia.htm (Fecha de descarga: 12/07/2020).

Valle Mejías, M. E. (2008). Aproximación a la indumentaria como símbolo cultural; un recorrido histórico. Revista de la SEECI, 16, 74-97. Recuperado de http://dx.doi.org/10.15198/seeci. 2008.16.74-97 (Fecha de descarga 4/7/2020).

Anuario de la Escuela de Historia Virtual - Año 11 - Nº 18 - 2020: pp. 133-157. ISSN: 1853-7049 
157 | Aida Liliana Morales Tejeda

Vigarello, G. (1991). Lo limpio y lo sucio, la higiene del cuerpo desde la Edad Media. Madrid: Alianza Editorial.

Yacou, A. (1997). Santiago de Cuba a la hora de la revolución de Santo Domingo (17901804). Del Caribe, 26, 74-86.

Zanetti, O. (2002). De miradas y encuentros, de Rafael Hernández. Catauro, 5, 187-190.

\section{Fuentes hemerográficas:}

Biblioteca Provincial Elvira Cape, Fondos Raros y Valiosos (BPECFRV).

El Redactor.

Para citar este artículo:

Morales Tejeda, Aida Liliana (2020). Peluquería y aseo: gusto francés y referentes de modernidad en el Santiago de Cuba decimonónico. Anuario de la Escuela de Historia Virtual, 18, 133-157. 